\section{DINAMIKA SOSIAL MASYARAKAT DESA}

Dinamika Sosial dalam masyarakat dapat terjadi jika ada interaksi sosial, kelompok sosial dan kelas sosial dalam suatu masyarakat. Masyarakat Desa memiliki keunikan tersendiri, seperti halnya masyarakat Desa yang berada di sekitar bukit Karampuang. Dalam buku ini banyak mendeskripsikan tentang Dinamika Sosial Masyarakat Desa yang berada disekitar Bukit Karampuang. Keberadaan bukit Karampuang sebagai tempat wisata dan ziarah yang ramai dengan pengunjung memiliki fungsi sosial yang berdampak kepada masyarakat sekitar. Pola interaksi antara masyarakat lokal dengan pengunjung terjadi dalam bentuk tukar menukar kepentingan.

Kedatangan pengunjung menghasilkan interaksi kultural yaitu suatu bentuk hubungan di mana basis sosial budaya yang menjadi modalnya. Dengan demikian bukit Karampuang ditinjau dari dimensi kultural dapat menumbuhkan interaksi antara masyarakat tradisional dengan masyarakat moderent. Melalui proses interaksi, maka memungkinkan adanya suatu pola saling mempengaruhi yang pada akhirnya akan mempengaruhi struktur kehidupan atau pola budaya masyarakat, khususnya masyarakat Desa yang menjadi tuan rumah.

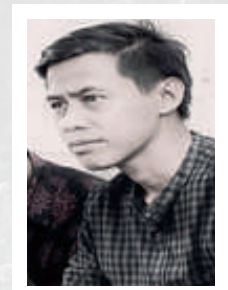

M. Rusdi lahir di Tanete, Kabupaten Bulukumba 15 September 1992. Pendidikan Tinggi S1 di Unismuh Makassar (2009-2015) dan S2 di Universitas Negeri Makassar (2015-2017) konsentrasi di Pendidikan Sosiologi. Penulis pernah aktif di beberapa lembaga sejak berstatus mahasiswa hingga sekarang (Lintas Sulsel 2010-2011, HMJ Sosiologi 2011-2012, HMI 2013-2014, Pemuda Muhammadiyah Cabang Namlea 2020-sekarang, ADPERTISI/ Aliansi Dosen PT Swasta Indonesia 2020-sekarang. Dan sekarang penulis aktif sebagai Dosen dan Ketua Program Studi KPI di Universitas Iqra Buru.

Karya Ilmiah yang telah dipublikasikan adalah: Solidaritas Sosial Masyarakat Petani Di Desa Wanareja Kabupaten Buru, Problem Sosial Anak Putus Sekolah (Studi Kasus Di Desa Lala Kabupaten Buru), Penerapan Sistem Informasi Manajemen Pendidikan dalam Proses Pembelajaran, Perubahan Sosial Sekitar Bukit Karampuang.

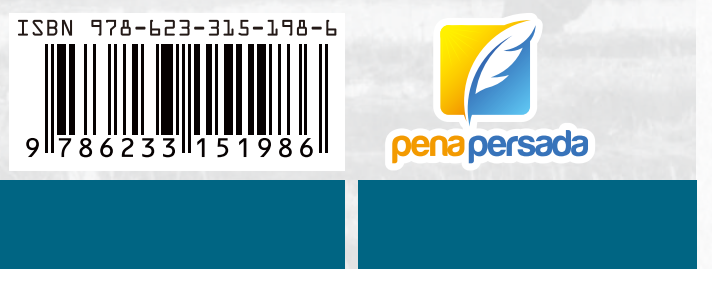

M. Rusdi

\section{DINAMIKA SUSIAL
MASYARAKAT DESA}

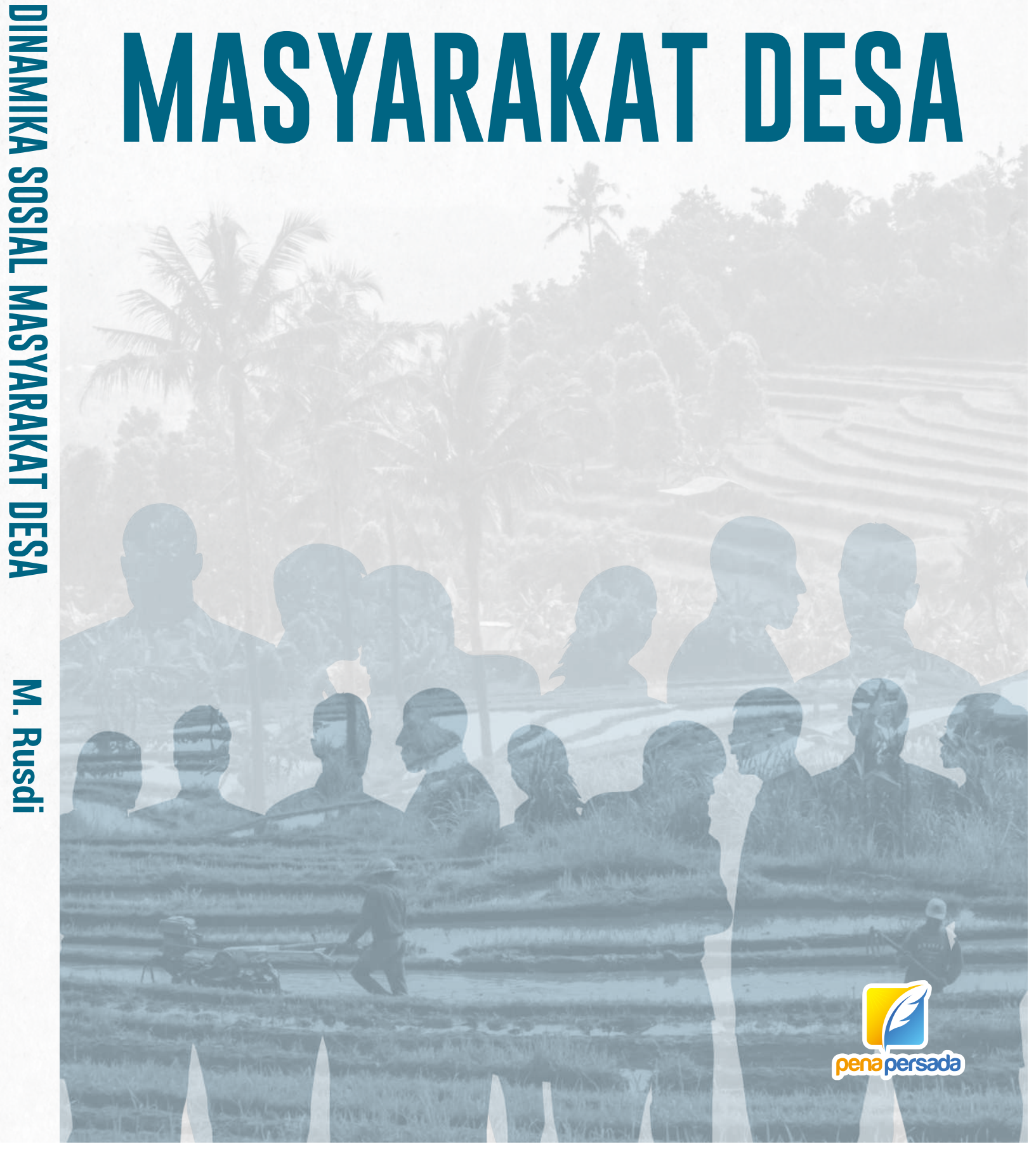


DINAMIKA SOSIAL MASYARAKAT DESA

M. RUSDI

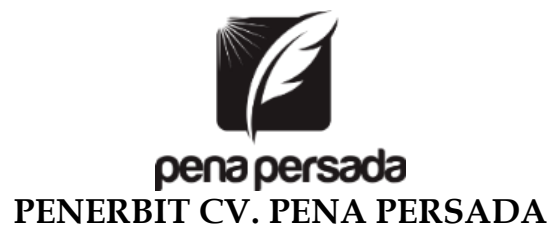




\title{
DINAMIKA SOSIAL MASYARAKAT DESA
}

\author{
Penulis: \\ M. Rusdi \\ ISBN : 978-623-315-198-6 \\ Editor: \\ Wiwit Kurniawan \\ Design Cover : \\ Retnani Nur Briliant \\ Layout : \\ Hasnah Aulia

\section{Penerbit CV. Pena Persada} \\ Redaksi : \\ Jawa Tengah \\ Email : penerbit.penapersada@gmail.com
}

Jl. Gerilya No. 292 Purwokerto Selatan, Kab. Banyumas

Website : penapersada.com Phone : (0281) 7771388

\section{Anggota IKAPI}

All right reserved

Cetakan pertama : 2020

Hak Cipta dilindungi oleh undang-undang. Dilarang memperbanyak karya tulis ini dalam bentuk apapun tanpa izin penerbit 


\section{KATA PENGANTAR}

Puji syukur saya panjatkan kepada Tuhan Yang Maha Esa, karena atas berkat dan rahmat-Nya, saya dapat menyelesaikan buku ini. Penulisan buku merupakan buah karya dari pemikiran penulis yang diberi judul "DINAMIKA SOSIAL MASYARAKAT DESA". Saya menyadari bahwa tanpa bantuan dan bimbingan dari berbagai pihak sangatlah sulit bagi saya untuk menyelesaikan karya ini. Oleh karena itu, saya mengucapkan banyak terima kasih pada semua pihak yang telah membantu penyusunan buku ini. Sehingga buku ini bisa hadir di hadapan pembaca.

Dinamika sosial dalam masyarakat dapat terjadi pada nilai-nilai sosial, norma-norma sosial, pola-pola perilaku organisasi, susunan lembaga kemasyarakatan, kekuasaan dan wewenang, interaksi sosial, dan lain sebagainya yang menjadi bagian dalam kehidupan masyarakat tersebut. Fenomena dinamika sosial terjadi pula dalam kehidupan masyarakat di Desa Barugae Kecamatan Bulukumpa Kabupaten Bulukumba. Secara historis masyarakat Desa Barugae memiliki pola hidup dan adat istiadat yang sedikit berbeda dengan masyarakat yang lain yang ada di Kabupaten Bulukumba. Pola hidup dan adat istiadat masyarakat umumnya memiliki kaitan dengan kepercayaan mereka terhadap animisme. Sehingga di wilayah Desa Barugae banyak tempat-tempat yang dianggap keramat oleh masyarakat. Dalam buku ini membahasa mengenai dinamika sosial masyarakat di sekitar bukit karampuang Desa Barugae Kecamatan Bulukumpa Kabupaten Bulukumba, sehingga nantinya dapat diketahui lebih jelas mengenai faktor penyebab terjadinya dinamika sosial, bagaimana interaksi antara masyarakat lokal dengan masyarakat pengunjung sehingga terjadi dinamika sosial dan dampak yang ditimbulkan terhadap masyarakat sekitar Bukit Karampuang. 
Penulis menyadari bahwa buku ini masih jauh dari kesempurnaan. Oleh karena itu kritik dan saran yang membangun sangat dibutuhkan guna penyempurnaan buku ini. Akhir kata saya berharap Tuhan Yang Maha Esa berkenan membalas segala kebaikan semua pihak yang telah membantu. Semoga buku ini akan membawa manfaat bagi pengembangan ilmu keperawatan.

Penulis 


\section{DAFTAR ISI}

KATA PENGANTAR iii

DAFTAR ISI $\mathrm{V}$

BAB I PENDAHULUAN

A. Dinamika Sosial Masyarakat Indonesia......................... 1

B. Fungsi Sosial Keberadaan Bukit Karampuang .............. 3

\section{BABII KONSEP DINAMIKA PERUBAHAN SOSIAL}

A. Dinamika Sosial............................................................. 5

B. Dinamika dan Norma Sosial ........................................... 11

C. Dinamika dan Medan Jaringan Sosial............................. 13

\section{BAB III BUKIT KARAMPUANG}

A. Gambaran Bukit Karampuang ....................................... 15

B. Interaksi Sosial ............................................................ 19

1. Geometri Sosial....................................................... 22

2. Tipe Sosial ................................................................... 24

3. Bentuk Sosial.............................................................. 25

C. Modernisasi ..................................................................... 25

D. Akulturasi .................................................................... 29

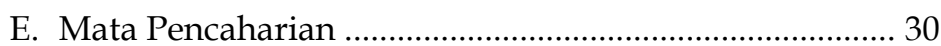

F. Westernisasi .................................................................... 31

\section{BAB IV GAMBARAN UMUM MASYARAKAT} BUKIT KARAMPUANG

A. Letak Geografis ................................................................... 33

B. Kehidupan Sosial Masyarakat Sekitar Bukit Karampuang Desa Barugae.............................................. 36

C. Pola Interaksi Sosial Masyarakat dengan

Pengunjung di Sekitar Bukit Karampuang .................... 44

D. Dampak Kedatangan Pengunjung Tehadap Masyarakat Bukit Karampuang...................................... 50

BAB V PROSES DINAMIKA SOSIAL MASYARAKAT DI SEKITAR BUKIT KARAMPUANG DESA BARUGAE ..

A. Faktor Yang Mendorong Terjadinya Dinamika Sosial ..

B. Kehidupan Sosial Budaya Masyarakat .......................... 57

Sekitar Bukit Karampuang Desa Barugae..................... 60

C. Pola Interaksi Sosial Masyarakat dengan Pengunjung di Sekitar Bukit Karampuang ..................... 72 
D. Dampak Kedatangan Pengunjung Terhadap

Masyarakat Sekitar Bukit Karampuang ………………..... 77

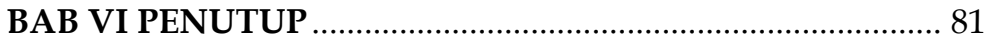




\section{BAB I \\ PENDAHULUAN}

\section{A. Dinamika Sosial Masyarakat Indonesia}

Indonesia merupakan Negara yang penduduknya terdiri dari berbagai macam suku, budaya dan adat istiadat yang berbeda-beda. Keberagaman tersebut termanifestasi dalam bentuk kepercayaan dan kebudayaan yang menjadi ciri khas dan kepribadian antara satu suku dengan suku yang lain.

Perubahan dalam kehidupan suatu masyarakat merupaka sebuah keniscayaan yang tidak dapat dihindari manusia, hal ini karena inti dari jiwa masyarakat sendiri adalah perubahan, masyarakat senantiasa berubah di semua tingkat kompleksitas internalnya. Dinamika sosial yang terjadi dalam kehidupan masyarakat adakalanya merupakan perubahan yang besar dan memiliki pengaruh yang luas, dan adakalanya hanya merupakan perubahan yang kecil dengan pengaruh yang sangat terbatas.

Dinamika sosial dalam masyarakat dapat terjadi pada nilai-nilai sosial, norma-norma sosial, pola-pola perilaku organisasi, susunan lembaga kemasyarakatan, kekuasaan dan wewenang, interaksi sosial, dan lain sebagainya yang menjadi bagian dalam kehidupan masyarakat tersebut. Apapun bentuk dan ragam dinamika yang terjadi dalam suatu masyarakat dapat dipastikan ada faktor sebagai agen perubahan tersebut, faktor ini adakalanya berupa individu dan kelompok.

Fenomena dinamika sosial terjadi pula dalam kehidupan masyarakat di Desa Barugae Kecamatan Bulukumpa Kabupaten Bulukumba. Secara historis masyarakat Desa Barugae memiliki pola hidup dan adat istiadat yang sedikit berbeda dengan masyarakat yang lain yang ada di Kabupaten Bulukumba. Pola hidup dan adat istiadat masyarakat umumnya memiliki kaitan dengan 
kepercayaan mereka terhadap animisme. Sehingga di wilayah Desa Barugae banyak tempat-tempat yang dianggap keramat oleh masyarakat.

Salah satu tempat yang dianggap keramat oleh masyarakat adalah bukit Karampuang. Bukit Karampuang secara etimologi berasal dari dua akar kata Karaeng dan Puang yang berarti gelar kebangsawanan yang kemudian di jadikan perbatasan antara wilayah golongan Karaeng dan Puang. Menurut Hasanuddin (2007:22), dulunya bukit Karampuang bernama bukit kayangan. Panorama yang melingkari kaki bukit cukup menyajikan suatu pemandangan eksotis, dari puncak bukit dengan leluasa mata kita dapat melihat gugusan pulau Sembilan di perairan Sinjai, melihat Kajang dengan rimbunan perkebunan karet Balombessi, melihat kota Tanete dan menguningnya padi di sela-sela pucuk pohon cengkeh. Alam "kayangan" begitu nyata kita temukan ketika kita tepat berada di puncak bukit tersebut yang kemudian dilengkapi pula dengan desau air terjun yang sesekali muncul ketika musim penghujan tiba.

Menurut Hasanuddin (2007:94) Situs Karampuang di puncak bukit terdapat bangunan sederhana yang terbuat dari konstruksi kayu yang dipercaya oleh masyarakat sebagai makam Syekh Abdullah. Secara historis Syek Abdullah adalah murid sekaligus teman dari Datuk Tiro yang diberikan tugas untuk menyebarkan agama islam di Kecamatan Bulukumpa, Syek Abdullah mula-mula muncul di puncak bukit yang kemudian juga wafat di puncak bukit dan dimakamkan sehingga banyak yang berziarah. Aktifitas ziarah makam tersebut ditandai dengan banyaknya simpul plastic yang diikatkan pada tiang atau dindin bangunan ini menunjukkan banyaknya nazar yang diucapkan oleh masyarakat pengunjung, sebab setiap peziarah yang dating membuat simpul yang kemudian baru dibuka kembali ketika cita-cita atau keinginan mereka telah terpenuhi. Tak jarang pula, aktifitas pembukaan simpul plastic diiringi dengan acara selamatan dengan memotong hewan seperti 
ayam, kambing bahkan seekor sapi yang kemudian di nikmati bersama dengan masyarakat sekitar bukit Karampuang.

\section{B. Fungsi Sosial Keberadaan Bukit Karampuang}

Keberadaan bukit Karampuang juga mempunyai fungsi sosial karena bagi masyarakat di luar desa Barugae bukit tersebut mempunyai daya tarik tersendiri sebagai obyek ritual, bernasar, siarah kubur sekaligus tempat wisata alam. Tingginya intensitas masyarakat pengunjung dari luar Desa, Kecamatan bahkan Kabupaten yang datang ke bukit Karampuang telah membawa pengaruh tersendiri terhadap kehidupan sosial masyarakat setempat, seperti dalam pola pikir dan perilaku masyarakat. Banyak hal yang dianggap baru oleh masyarakat sekitar dibawa oleh pengunjung khususnya pemuda ataupun remaja, mulai dari gaya rambut, cara berpakaiyan, bahasa dan seterusnya kemudian diinternalisasi oleh masyarakat sekitar dan dimanifestasikan dalam kehidupan sehari-hari.

Sistem mata pencaharian masyarakat desa Barugae dulunya hanya bertani sekaran sudah mulai lebih kreatif dengan cara berjualan disekitar bukit dalam rangka mencari penghasilan tambahan. Selain itu keseharian kehidupan masyarakat telah merespon perkembangan teknologi dan kesadaran akan pentingnya pendidikan, yang dulunya hanya sampai tingkat SD sekarang sudah banyak diantara mereka yang menyekolahkan anaknya sampai ke jenjang sarjana. Dari perkembangan itulah kemudian dunia lokal yang cenderung tradisional, berkembang jadi global yang mengarah ke modern. Dan dengan segala konsekuensi, dunia lokal mengalami perubahan.

Beberapa studi tentang perubahan sosial yang pernah di ungkap oleh para peneliti terdahulu, seperti halnya studi yang dilakukan oleh H. Muhammad Taufik (2011) dengan memusatkan kajiannya pada "Perubahan Fungsi Ritual Makam Syekh Yusuf dan Kehidupan Sosial Ekonomi Masyarakat di Kelurahan Katangka Kabupaten Gowa". 
Studi ini mengungkap bahwa, faktor penyebab perubahan fungsi ritual makam Syekh Yusuf Al Makassari akibat arus modernisasi sehingga keyakinan terhadap nilai-nilai ajaran agama Islam serta norma budaya lokal melemah. Menyebabkan ritual ziarah yang dilakukan cinderung sinkretisme, yang selanjutnya dalam proses perkembangannya menyebabkan lonjakan pertambahan penduduk di Kelurahan Katangka. Studi ini juga menyimpulkan bahwa perlunya upaya mengoptimalkan dampak perubahan fungsi ritual makam Syekh Yusuf Al Makassari melalui konsep pemberdayaan masyarakat Kelurahan Katangka lebih baik. 


\section{BAB II \\ KONSEP DINAMIKA \\ PERUBAHAN SOSIAL}

\section{A. Dinamika Sosial}

Kata dinamika berasal dari kata dynamics (yunani) yang bermakna "kekuatan" (force). "Dynamics is factsor concepts which referto conditions of change, expeciallyto forces". Dinamika berarti tingkah laku warga yang satu secara langsung mempengaruhi warga yang lain secara timbal balik. Dinamika berarti adanya interaksi dan interpendensi antara anggota kelompok yang satu dengan anggota kelompok secara keseluruhan (Santoso, 2004:5).

Menurut istilah Pierre Bourdeu, dinamika tersebut mencerminkan sebuah struktur yang menstrukturkan dan struktur yang distrukturkan. Maksudnya, ada sebuah struktur yang megalami proses in dan out yang menyebabkan struktur tersebut berada pada posisi yang tidak stagnan. Proses semacam ini oleh antropolog George Balandier, dalam antropologi Politique, mewujud dalam internalisasi dan eksternalisasi yang menyebabkan terjadinya dinamika tersebut (Abdullah, Wening dan Hasse, 2009:1).

Dinamika perubahan sosial, dapat dibayangkan sebagai perubahan yang terjadi di dalam atau mencakup sistem sosial. Lebih tepatnya terdapat perbedaan antara keadaan sistem tertentu dalam jangka waktu berlainan. Perbedaan keadaan yang diamati antara sebelum dan sesudah jangka waktu tertentu' untuk dapat menyatakan perbedaannya, ciri-ciri awal unit analisis harus diketahui dengan cermat-meski terus berubah, Stasser \& Randall dalam Sztompka (2004: 3).

Beberapa penjelasan dan pengertian tentang dinamika yang dikemukakan oleh beberapa para ahli tersebut dapat disimpulkan bahwa dinamika perubahan sosial adalah sebuah tingkah laku yang dilakukan baik masyarakat 
maupun individu yang mempengaruhi masyarakat lain dengan berbagai faktor.

Dinamika social bukanlah sebuah proses yang terjadi secara tiba-tiba, terlebih lagi ketika dinamika tersebut melibatkan individu atau kelompok social sebagai target perubahan. Untuk itu, konsep dasar mengenai dinamika perubaha social menurut (Stompka, 2004) menyangkut tiga hal, yaitu:

1. Studi mengenai perbedaan

2. Studi harus dilakukan pada waktu yang berbeda

3. Pengamatan pada system social yang sama

Studi dinamika perubahan sosial, dengan demikian akan melibatkan dimensi ruang dan waktu. Dimensi ruang menunjuk pada wilayah terjadinya perubahan sosial serta kondisi yang melingkupinya. Dimensi waktu dalam studi dinamika perubahan sosial meliputi konteks masa lalu (past), sekarang (present), dan masa depan (future). Dalam segi aspek masa lalu menjadi bagian proyeksi yang akan terjadi pada masyarakat yang akan datang. Namun sosiolog bukanlah peramal, karena sosiologi melakukan peramalan melalui metode ilmiah yang dapat dipertanggunjawabkan.

Menurut Sztompka (2004: 3-4) Perubahan sosial dapat dibedakan menjadi beberapa jenis, tergantung pada sudut pengamatan: apakah dari sudut aspek, fragmen atau dimensi sistem sosialnya. Ini disebabkan keadaan sistem sosial itu tidak sederhana, tidak hanya berdimensi tunggal, tetapi muncul sebagai kombinasi atau gabungan hasil keadaan berbagai komponen seperti berikut:

1. Unsur-unsur pokok (misalnya: jumlah dan jenis individu, serta tindakan mereka)

2. Hubungan antaraunsur (misalnya: ikatan sosial, loyalitas, ketergantungan, hubungan antar individu, intelegrasi)

3. Berfungsinya unsur-usur dalam sistem (misalnya: peran pekerjaan yang dimainkan oleh individu atau 
diperlukannya tindakan tertentu untuk melestarikan ketertiban sosial)

4. Pemeliharaan batas (misalnya: kriteria untuk menentukan siapa saja anggota sistem, syarat penerimaan individu dalam kelompok, prinsip rekrutmen dalam organisasi, dan sebagainya)

5. Subsistem (misalnya: jumlah dan jenis seksi, segmen, atau divisi khusus yang dapat dibedakan)

6. Lingkungan (misalnya: keadaan alam atau lokasi geopolitik).

Pendapat tersebut menunjukan tentang beberapa perubahan sosial yang dibedakan dalam berbagai jenis dan sudut pandang dalam pengamatan yang tidak hanya berdimensi tunggal. Tetapi ia muncul sebagai kombinasi dari berbagai gabungan komponen-komponen yang ada, dan memiliki keterkaitan antara yang satu dan yang lainnya sehingga perubahan sosial terjadi dalam masyarakat.

Dinamika perubahan sosial dalam masyarakat dibayangkan berada dalam keadaan tetap yang dapat dianalisis sebelum terjadi, atau terlepas dari perubahan. Perubahan sosial meliputi 'atom' terkecil dinamika sosial, perubahan keadaan sistem sosial atau perubahan di setiap aspeknya. Tetapi perubahan tunggal jarang terjadi dalam keadaan terisolasi. Perubahan itu biasanya berkaitan dengan aspek lain dalam sosiologi.

Menurut Sztompka (2004: 8), Ada dua kecenderungan intelektual yang menonjol dalam dinamika kehidupan sosial: (1) Penekanan pada kualitas dinamis realitas sosial yang dapat menyebar kesegala arah, yakni membayangkan masyarakat dalam keadaan bergerak (berproses); (2) tidak memperlakukan masyarakat (kelompok, organisasi) sebagai sebuah obyek dalam arti menyangkal konkretisasi realitas sosial.

Implikasi pertamanya adalah bahwa pertentangan antara keadaan statis dan dinamis mungkin hanya ilusi dan tak ada obyek atau struktur atau kesatuan tanpa mengalami 
perubahan. Pemikiran ini berasal dari ilmu alam. Alfred N. Whitehead dalam Sztompka (2004: 9) menyebutnya sebagai konsep "perubahan menjadi sifat sesuatu". Pandangan dinamis ini segerah berubah menjadi pendekatan dominan, menjadi kecenderungan ilmu modern untuk lebih memerhatikan peristiwa ketimbang keadaanya sebagai komponen utama realitas.

Dari pendapat tersebut masyarakat tidak boleh dibayangkan sebagai keadaan yang tetap, tetapi sebagai proses; bukan sebagai obyek semu yang kaku tetapi sebagai aliran peristiwa terus menerus tanpa henti. Diakui bahwa masyarakat (kelompok, komunitas, organisasi, bangsa, negara) hanya dapat dikatakan ada sejauh dan selama terjadi di dalamnya, ada tindakan tertentu yang dilakukan, ada perubahan tertentu, dan ada proses tertentu yang senantiasa bekerja. Secara ontologi dapat dikatakan bahwa masyarakat tak berada dalam keadaan tetap terus-menerus. Semua realitas sosial senantiasa berubah dengan derajat kecepatan, intensitas, irama dan tempo yang berbeda. Bukan kebetulan jika orang berbicara mengenai "kehidupan sosial". Karena kehidupan adalah gerakan dan perubahan, maka bila berhenti tak ada lagi kehidupan melainkan merupakan suatu keadaan yang sama sekali berbeda yang disebut ketiadaan atau kematian.

Menurut Sztompka (2004:11) ada empat jenis ikatan yang muncul dalam masyarakat yang saling berkaitan, tergantung pada jenis kesatuan yang dipersatukan oleh jaringan hubungan itu, yakni ikatan:

1. Gagasan. Jaringan hubungan gagasan merupakan dimensi ideal dari kehidupan bersama, yakni "kesadaran sosialnya".

2. Normatif. Jaringan hubungan aturan (norma, nilai, ketentuan, dan cita-cita) merupakan dimensi normatif dari kehidupan bersama, yakni (institusi sosialnya)

3. Tindakan. Jaringan hubungan tindakan merupakan dimensi interaksi dalam kehidupan bersama, yakni "organisasi sosialnya". 
4. Perhatian. Jaringan hubungan perhatian (peluang hidup, kesempatan, akses terhadap sumber daya) merupakan dimensi kesempatan kehidupan bersama, yakni "heirarki sosialnya".

Pendapat tersebut menunjukan bahwa faktor terjadinya interaksi, itu dipengaruhi oleh berbagai jenis ikatan yang muncul antara pengunjung dengan masyarakat sekitar Bukit Karampuang yang saling berkaitan dan tergantung pada jenis kesatuan yang dipersatukan oleh jaringan. Salah-satunya adalah ikatan kesamaan gagasan, normatif yang memengaruhi apa yang secara tradisional dikenal sebagai kebudayaan. Sedangkan ikatan tindakan atau jaringan hubungan tindakan merupakan dimensi interaksi dalam kehidupan bersama yakni "organisasi sosialnya" dan jaringan hubungan perhatian (peluang hidup, kesempatan, akses terhadap sumber daya) merupakan dimensi kesempatan kehidupan bersama, yakni "heirarki sosialnya". Dimensi interaksi dan kesempatan ini memperkuat ikatan sosial dalam arti sebenarnya. Ikatan itulah yang menjadi

Pendorong terjadinya interaksi yang kemudian menimbulkan dinamika sosial di masyarakat sekitar bukit Karampuang.

Soerjono Soekanto (2010: 101) mengatakan bahwa ada 2 faktor yang mempengaruhi terjadinya dinamika sosial dapat digolongkan, yakni faktor dari dalam dan luar masyarakat. Faktor yang berasal dari dalam. Pertama, bertambah dan berkurangnya penduduk. Pertambahan jumlah penduduk akan menyebabkan perubahan jumlah dan persebaran wilayah pemukiman. Wilayah pemukiman yang berpusat pada satu wilayah kekerabatan akan berubah atau terpancar karena faktor pekerjaan. Hal ini bisa ditinjau secara geografis bahwa masyarakat Bukit Karampuang telah melakukan migrasi untuk bekerja di masyarakat perkotaan. Berkembangnya penduduk juga akan menyebabkan dinamika sosial. 
Kedua, penemuan-penemuan baru. Tidak bisa dipungkiri bahwa dengan adanya arus modernisasi. Misalnya kehadiran teknologi akan mempengaruhi pola interaksi masyarakat. Perkembangan teknologi juga dapat mengurangi jumlah kebutuhan tenaga kerja di sector industry karena tenaga manusia telah tergantikan oleh mesin yang menyebabkan proses produksi semakin efektif dan efisien. Misalnya, dalam masyarakat pedesaan melakukan pekerjaan di sawah dulunya mengandalkan hewan dan tenaga manusia kini tergantikan dengan adanya mesin traktor.

Ketiga, pertentangan atau konflik. Pertentangan dalam suatu system social akan menyebabkan dinamika perubahan social secara kultur dan struktur, baik secara fungsional maupun disfungsional.

Keempat, terjadinya pemberontakan atau revolusi. Terjadinya pemberontakan tentu saja akan melahirkan berbagai perubahan, pihak pemberontak akan memaksakan tuntutannya, lumpuhnya kegiatan ekonomi, pergantian kekuasaan, dan sebagainya.

Faktor yang berasal dari luar. Pertama, terjadinya bencana alam atau kondisi lingkungan fisik, hal tersebut bisa kita lihat bagaimana terjadinya bencana banjir Tsunami di Aceh, lumpur lapindo di Sidoarjo, dan Gunung Merapi meletus di Yogyakarta. Kondisi ini terkadang memaksa masyarakat suatu daerah untuk mengungsi meninggalkan tanah kelahirannya.

Kedua, peperangan. Peristiwa peperangan, baik peran saudara maupun perang antarnegara dapat menyebabkan dinamika sosial, karena pihak yang menang biasanya akan memaksakan ideology dan kebudayaannya kepada pihak yang kalah.

Ketiga, adanya pengaruh kebudayaan masyarakat lain. Interaksi antara kebudayaan dapat diterima tanpa paksaan, maka disebut demonstration effect.

Adapun faktor yang mempercepat proses perubahan social adalah pertama, kontak dengan budaya lain atau yang 
dengan istilah "akulturasi". Bertemunya budaya yang berbeda menyebabkan manusia saling berinteraksi dan mampu menghimpun berbagai penemuan yang telah dihasilkan, baik dari budaya asli maupun budaya asing, dan bahkan hasil perpaduannya. Contohnya kebanyakan pendatang dari Etnis Tionghoa yang tinggal menetap di Kota Makassar mereka tetap memegan budayanya secara baik.

Kedua, sistem pendidikan formal yang maju. Pendidikan merupakan suatu instrument penting dalam mengukur suatu kemajuan sebuah masyarakat. Pendidikan telah membuka pikiran dan membiasakan berpola pikir ilmiah, rasional, dan objektif. Saat ini masyarakat bukit Karampuang telah banyak meninggalkan pola kehidupan yang lama. Masyarakat bukit Karampuang ketika telah lulus pada tingkat menengah atau atas dinilai sudah cukup, tetapi sekarang lebih mendorong anaknya untuk melanjutkan tingkat pendidikannya ke jenjang yang lebih tinggi misalnya dalam meraih gelar sarjana.

Ketiga, sikap menghargai hasil karya seseorang dan keinginan untuk maju. Sebuah hasil karya dapat memotifasi seseorang untuk mengikuti jejak kaya orang lain. Keempat, adanya toleransi terhadap perbuatan-perbuatan yang menyimpang. Berbeda halnya masyarakat bukit Karampuang yang memiliki sistem masyarakat terbuka (open stratication), sehingga arus perubahan social yang terjadi begitu cepat.

Adapun faktor yang mempercepat proses perubahan social. Pertama, banyaknya hubungan dengan masyarakat lain. Kedua, perkembangan ilmu pengetahuan yang begitu cepat. ketiga, sikap masyarakat yang mulai modern.

\section{B. Dinamika dan Norma Sosial}

Pernyataan bahwa manusia adalah mahluk sosial atau mahluk yang hidup bersama (masyarakat) merupakan pernyataan umum dalam konsep sosiologi. Hidup bersama atau hidup bermasyarakat dapat diartikan sama dengan 
hidup dalam suatu pergaulan. Hal ini menandakan bahwa manusia tidak pernah hidup dalam suatu isolasi, absolut dan permanen. Dinamika sosial yang mengandung interaksi antar manusia tumbuh sebagai suatu keharusan karena kondisi bio-psikologis manusia yang dilahirkan dengan basic drive dan basic needs yang harus dipenuhi. Oleh karena itu, manusia memerlukan tata aturan dalam bertindak kepada sesamanya satu sama lain. Jelasnya, dalam kehidupan manusia itu memerlukan pengaturan tata hubungan sehingga manusia dapat hidup dalam suasana yang harmonis. Gambaran tersebut pada dasarnya lebih mengacu pada pentingnya norma-norma di dalam hidup bermasyarakat.

Norma-norma sosial dalam kehidupan masyarakat merupakan bentuk peraturan yang tak tertulis yang berfungsi sebagai pengatur sikap dan perilaku manusia dalam pergaulan hidup sehari-hari dalam masyarakat. Norma sosial relatif banyak menekankan pada sangsi moral sosial sebagai unsur pengawasan terhadap sikap dan perilaku manusia dalam pergaulan tersebut.

Norma sosial sebagai unsur kebudayaan non-materil dapat berfungsi sebagai landasan kekuatan pribadi dalam upaya melindungi diri dari ancaman kejahatan moral atau pengaruh-pengaruh buruk dari luar. Dalam rangka upaya itu, norma atau kaidah sosial pada dasarnya merupakan petunjuk ideal tentang bagaimana seharusnya manusia berperilaku dalam pergaulan hidup bermasyarakat, (Soedjono dalam Farida Dawi 2010:33).

Sehubungan dengan yang diuraikan di atas, maka norma itu dapat dipandang sebagai suatu standar atau skala yang terdiri dari berbagai kategori perilaku yang berisikan suatu keharusan, larangan ataupun kebolehan. Karena norma itu telah dikonsepsikan demikian, sudah sewajarnya apabila interaksi atas dasar norma itu, artinya bahwa norma itu dielaborasikan dalam dinamika sosial. Pernyataan masyarakat seperti susila, dan sopan santun, memberi 
petanda bahwa hubungan antara manusia didasarkan pada suatu pola yang disebut norma.

Dinamika sosial yang mengandung interaksi dan interaksi tidak saja berkolerasi dengan norma sosial sebagai korelasi searah, tetapi melalui nilai-nilai dinamika sosial itu mewujudkan norma-norma sosial. Nilai-nilai merupakan ukuran terhadap sesuatu yang baik dan sesuatu yang buruk, sesuatu yang pantas dan sesuatu yang tidak pantas. Dinamika sosial yang merupakan hubungan atau interaksi sosial menumbuhkan pengalaman yang dapat diketahui dari perilaku yang disukai dan tidak disukai. Perilaku yang dusukai itu memberikan kemungkinan untuk dilakukan secara berulang-ulang. Hal ini akan menimbulkan bibit kebiasaan yang kemudian akan menjadi tata kelakuan serta mengalami pelembagaan dalam masyarakat. Selanjutnya, proses dinamika sosial yang terus menerus akan menimbulkan pola tertentu yang disebut dengan cara atau usage yakni: "A uniform or customary way of behafing withing a social group" yang dalam perkembangan selanjutnya, caracara yang diterapkan, mungkin menimbulkan kebiasaan atau folkways. Menurut George A. Theodorson dalam (Farida Dawi 2010: 34).

Apabila kebiasaan tersebut diakui serta diterimah sebagai akidah, kebiasaan tersebut menjadi tata kelakuan atau "mores". Akhirnya, karena adanya proses sosialisasi sejak awal, maka mores tersebut akan menjadi kebiasaan atau custom.

\section{Dinamika dan Medan Jaringan Sosial}

Uraian terdahulu telah memberikan konfigurasi awal dari suatu korelasi antara dinamika sosial dengan norma. Kajian dinamika sosial dalam suatu struktur bermula dalam ruang lingkup masyarakat kecil dan masih sederhana. Fenomena yang dikaji masih terbatas pada relasi antar keluarga kerabat dan ketetanggaan.

Menurut Redfield (1956: 17) Konsekwensi suatu masyarakat bagian dari suatu masyaraakat yang lebih luas, 